\title{
MEMAKNAI KEMBALI KONSEP NUSYUZ DALAM KOMPILASI HUKUM ISLAM PERSPEKTIF GENDER \& MAQASHID SYARIAH JASSER AUDA
}

\author{
${ }^{1}$ Muhammad Habib Adi Putra dan ${ }^{2}$ Umi Sumbulah \\ 1,2Pascasarjana UIN Maulana Malik Ibrahim Malang

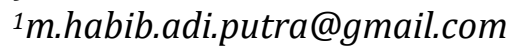 \\ ²umisumbulah@uin-malang.ac.id
}

\begin{abstract}
Some contemporary islamic religionists opinoin that the concept of nusyuz in clause 84 of the Islamic Law Compilation (KHI) is discriminatory against women. In that clause, many obligations are delegated to women. If the wife is unable to carry out her obligations, then the nusyuz law applies, but not for the husband. In this context, there are ambivalence, ambiguity, and injustice of law. Therefore, this paper discusses the meaning of nusyuz in KHI from a gender perspective and its relevance in the development of Islamic law in Indonesia. This literature research with a historical approach and gender analysis shows: first, the relevance of the concept of nusyuz in fiqh and KHI lies in the legal implications that are implied from the understanding of the substance of textuality; second, the re-meaning of the concept of nusyuz through the approach of the maqashid al-syariah system of Jasser Auda that in order to protect and develop women's human rights is to complement the concept of husband nusyuz in clause $84 \mathrm{KHI}$. Thus, the principles of equality and justice are important aspects in reinterpreting the concept of nusyuz, which can be done by both wives and husbands.
\end{abstract}

Keywords: Gender, Compilation of Islamic Law, Maqashid al-Syariah, Nusyuz

\section{Abstrak}

Sebagian ulama kontemporer memandang bahwa konsep nusyuz dalam pasal 84 Kompilasi Hukum Islam (KHI) bersifat diskriminatif terhadap perempuan. Dalam pasal tersebut setidaknya hak dan kewajiban banyak dilimpahkan terhadap perempuan. Jika istri tidak dapat menjalankan kewajiban, maka berlaku hukum nusyuz, namun tidak berlaku sebaliknya bagi suami. Dalam konteks ini maka terdapat ambivalensi, ambiguity, dan ketidakadilan suatu hukum. Karena itu, tulisan ini mendiskusikan kembali makna nusyuz dalam KHI perspektif gender dan relevansinya dalam perkembangan hukum Islam di Indonesia. Penelitian pustaka dengan pendekatan historis dn analisis gender ini menunjukkan: pertama, relevansi konsep nusyuz dalam fikih dan KHI terletak pada implikasi hukum yang tersirat dari pemahaman pada substansi tekstualitas; kedua, pemaknaan kembali konsep nusyuz melalui pendekatan sistem maqashid al-syariah Jasser Auda bahwa dalam rangka melindungi dan mengembangkan hak asasi 
perempuan adalah dengan menambahkan konsep nusyuz suami pada pasal 84 KHI. Dengan demikian, prinsip kesetaraan dan keadilan menjadi aspek penting dalam memaknai kembali konsep nusyuz, yang bisa saja dilakukan baik oleh isteri maupun suami.

Kata Kunci: Gender, Kompilasi Hukum Islam, Maqashid al-Syariah, Nusyuz

\section{PENDAHULUAN}

Diskriminasi gender karena kuasa patriarkhi merupakan isu-isu yang hingga kini masih menarik diperbincangkan dan dikaji secara serius. Dalam beberapa kesempatan, para aktivis Muslim dari berbagai negara muslim berkumpul untuk saling bertukar pengalaman, berdebat, dan mencari solusi yang relevan dan kontekstual untuk mengakhiri berbagai bentuk diskriminasi yang dialami kaum perempuan di negara mereka masingmasing, terutama yang berkaitan dengan kehidupan rumah tangga. Diskriminasi berdasarkan jenis kelamin telah melahirkan berbagai bentuk ketimpangan dan ketidakadilan gender, mereduksi dan mengabaikan hakhak perempuan. Meskipun dunia telah mengalami perkembangan yang amat pesat, akan tetapi realitas masih memperlihatkan adanya hak-hak perempuan yang terabaikan. Perempuan masih saja diposisikan sebagai makhluk Tuhan kelas dua. Kaum perempuan masih dilemahkan dan didiskriminasikan hampir dalam seluruh ruang hidupnya, domestik dan publik. Bahkan dalam sistem hukum dan perundang-undangan, khususnya dalam hukum keluarga di berbagai negara masih sarat dengan muatanmuatan (materi) yang belum melindungi dan memberikan hak-hak yang adil bagi perempuan (Wahid, 2014).

Pandangan diskriminatif terhadap perempuan ini juga terlihat dalam rumusan pasal dalam Kompilasi Hukum Islam (KHI), yang lahr melalui Inpres no. 1 tahun 1991. KHI lahir sebagai hasil perkembangan politik hukum Islam di Indonesia yang menyangkut hukum perkawinan, kewarisan dan perwakafan yang menjadi pedoman dan sumber hukum materiil bagi setiap putusan Pengadilan Agama.

Mengingat pentingnya peran KHI yang merupakan produk hukum berlabel Islam dan salah satu sarana bagi umat Islam dalam memperoleh keadilan, akan tetapi dalam kenyataannya masih terdapat pasal-pasal yang seharusnya dirubah dan disesuaikan dengan perkembangan. Beberapa pasal dalam KHI secara prinsipil dinilai bertentangan dengan prinsip dasar Islam yang universal, seperti persamaan (al-musawah), persaudaraan (alukhuwwah), dan keadilan (al-'adalah). Sejumlah pasal KHI sudah tidak lagi sesuai dengan peraturan perundang-undangan yang berlaku dan konvensi 
Internasional yang telah diratifikasi. Disamping itu, dari sudut pandang metodologi, KHI masih terkesan replika terhadap pemikiran ulama terdahulu. Konstruksi hukum KHI belum dikerangkakan sepenuhnya dalam konteks dan perspektif masyarakat Islam Indonesia (Wahid, 2014). Demikian juga konsep pembahasan nusyuz, konsep nusyuz dalam KHI merupakan salah satu objek pembahasan dari beberapa pasal yang dinilai diskriminatif, karena hanya mengatur perihal nusyuz istri dan tidak mengatur nusyuz pihak suami.

Berdasarkan beberapa alasan serta aturan di atas dalam situasi sosial hari ini dipandang telah menimbulkan ketidakadilan hukum bagi perempuan. Perempuan dalam institusi keluarga kini tidak bisa lagi dipandang sebagai subordinasi laki-laki dengan alasan peran dan posisi perempuan dalan realitas sosial sekarang sangat berbeda dengan kondisi perempuan pada zaman dahulu. Perempuan dalam konteks saat ini relatif merata dan umum sudah terbukti memiliki kecakapan bertindak, kecerdasan memilih dan kemandirian dalam banyak urusan transaksional. Di samping itu, hal tersebut tidak sejalan dengan cita-cita hukum Islam dan tujuan setiap hukum dan perundang-undangan dimanapun yaitu keadilan dan kemashlahatan individu masyarakat dan bangsa. Oleh karena itu, perlu kiranya mereinterpretasi ulang konsep nusyuz dalam KHI dengan melihat konteks sosial pada saat ini serta mengkaji ulang idea moral pada fikih yang sudah tidak relevan jika dilihat dari perspektif gender dan Maqashid al-syari'ah Jasser Auda yang berbasis pada pengembangan dan perlindungan Hak-Hak Asasi dengan menggunakan pendekatan sistem. Hasil interpretasi tersebut dapat dijadikan bahan rekonseptualisasi nusyuz dalam KHI yang dalam hal ini adalah dalam pasal 84 yang memuat penjelasan umum tentang nusyuz dan merupakan point of interest dalam pembahasan konsep nusyuz yang berkesetaraan dan berkeadilan gender.

\section{METODE PENELITIAN}

Penelitian ini menggunakan pendekatan perundang-undangan (statute approach), dengan mengkaji peraturan perundang-undangan yang berlaku, untuk menelaah konsep nusyuz dalam pasal 84 Kompilasi Hukum Islam. Pendekatan konseptual (conceptual approach) juga digunakan untuk memahami doktrin penting yang berkembang di dalam ilmu hukum dapat menjadi pijakan untuk membangun argumentasi hukum ketika menyelesaikan isu hukum yang dihadapi (Marzuki, 2016). Jenis penelitian pustaka ini menggunakan data dan bahan kajian dari sumber-sumber kepustakaan melalui teknik dokumentasi. Analisis data kualitatif ini menggunakan teknik deskriptif-kualitatif untuk mendeskripsikan secara 
jelas konsep nusyuz dalam Kompilasi Hukum Islam dengan perspektif gender dan maqashid al-syariah Jassir Auda (Muhammad, 2004).

\section{PEMBAHASAN}

\section{Relevansi Konsep Nusyuz dalam Fikih dan Kompilasi Hukum Islam}

Pemahaman fikih klasik tentang nusyuz bersinggungan dengan konteks masyarakat Arab sebagai sebab khusus turunnya surat an-Nisa (4): 34. Kondisi geografis yang agraris tanah Arab menempatkan laki-laki sebagai otoritas tunggal dalam mencari nafkah keluarga, pun medan peperangan antara Islam dan non-Islam juga diwajibkan untuk laki. Dua kenyataan tersebut menimbulkan setting budaya patriarkhi yang melahirkan asumsi kolektif, bahwa laki-laki lebih kuat dari perempuan, dan perempuan bersifat lemah (Nasution, 2004).

Ketentuan nusyuz dalam KHI merupakan legitimasi fikih, yang menempatkan perempuan pada sudut khusus. Kendati KHI tidak memberikan arti nusyuz yang jelas, namun konsep dan implikasi hukum yang ditampilkan dinilai "lebih keras" dibandingkan fikih klasik. Konsep nusyuz dalam pasal 84 ayat 1 dan Pasal 83 ayat $1 \mathrm{KHI}$ terfokus pada penyimpangan kewajiban-kewajiban istri sebagai indikator nusyuz. Dari konsep ini dapat diketahui bahwa nusyuz adalah bentuk pembangkangan atau penyimpangan kewajiban istri kepada suami. Implikasi hukum dari penyimpangan tersebut sebagaimana tertera dalam pasal 80 ayat 7, pasal 84 ayat 2, dan pasal 152 KHI, menghilangkan hak-hak istri secara penuh. Implikasi hukum nusyuz bukan saja persoalan bentuk hukum berupa ketiadaan nafkah, melainkan keadilan dan kemanfaatan hukum bagi perempuan.

Ketentuan nusyuz dalam KHI tidak sepenuhnya meng-copy paste fikih klasik. Kendati esensi KHI dengan fikih klasik sama-sama menyudutkan hakhak perempuan dibandingkan laki-laki, akan tetapi terdapat nilai-nilai hukum yang mempertemukan keduanya. KHI yang pada penyusunannya melibatkan banyak tahap, termasuk penelusuran yurisprudensi dan studi banding ke negara-negara Islam dengan konteks yang berbeda, menjadikan KHI komprehensif sebagai aturan hokum (Wahid, 2014). Relevansi nilai antara KHI dan fikih klasik ditemukan dalam beberapa analisis aspek berikut:

Pertama, aspek ruang lingkup nusyuz. Pemaknaan nusyuz menurut imam mazhab (Hanafi, Maliki, Syafi'i dan Hambali) secara umum disimpulkan dengan arti nusyuz, yaitu sikap yang menimbulkan ketidaknyamanan dalam keluarga, baik ditimbulkan oleh istri maupun suami, dan perasaan tidak senang dari pihak istri maupun suami yang disertai dengan pergaulan yang tidak harmonis. Dengan demikian, nusyuz sebenarnya merupakan kondisi 
dalam keluarga yang menyimpang dari tujuan perkawinan. Dalam hukum positif, tujuan hukum merupakan rujukan untuk mengembalikan segala masalah yang berkenaan dengan hukum dan dikategorikan sebagai asas hukum (Ali, 2015). Tujuan perkawinan adalah untuk menciptakan keluarga yang sakinah, mawaddah wa rahmah. Karena itu, nusyuz merupakan kondisi sebaliknya yang secara diametral berlawanan dengan tujuan perkawinan. Dengan demikian, antara fikih klasik dengan KHI memiliki pemaknaan yang memiliki kemiripan tentang nusyuz.

Kedua, indikator nusyuz dengan konsep mafhum muwāfaqāt sebagai salah satu istimbāt al-hukm. Indikator nusyuz dalam pasal 84 ayat $1 \mathrm{KHI}$ menyebutkan bahwa istri dianggap melakukan perbuatan nusyuz apabila tidak melaksanakan kewajiban-kewajibannya. Sementara implikasi hukum terhadap suami apabila melanggar kewajibannya, KHI tidak mengatur dengan jelas. Degan demikian, ketidakjelasan implikasi hukum terhadap suami dapat menimbulkan pemahaman bahwa KHI berpihak kepada suami dengan mengesampingkan keberadaan istri.

Dalam menentukan peristiwa hukum, ulama fikih -salah satunyamenggunakan konsep dalālaț an-Nās dalam menggali hukum dari nās alQuran dan hadis. Salah satu konsep dalālaț an-Nās tersebut adalah mafhum muwāfaqāt, yaitu berlakunya hukum pada peristiwa yang tidak disebutkan dalam nās lebih pantas dibandingkan dengan hukum pada lafadz (Khallaf, 2004). Dengan demikian, dalam KHI kendati implikasi hukum terhadap suami tidak disebutkan, namun hukum asalnya disebutkan, maka secara tidak langsung implikasi hukum terhadap istri juga berlaku untuk suami. Dengan demikian, relevansi antara fikih dengan KHI tertera dalam konsep nusyuz dan implikasi hukum tersirat dari pemahaman teks tertulis. Untuk memahami teks perundang-undangan maupun fikih, harus memahami tentang konsep teks dan tujuan dari dibuatnya teks tersebut (Zahrah, 1994). Maka dapat dipahami, relevansi keduanya terletak pada substansi nās atau teks.

\section{Konsep Nusyuz dalam KHI Perspektif Maqāșid al-Sharī'ah Jasser Auda a. Fitur Watak Kognisi (Cognitive Nature)}

Berdasarkan perspektif teologi Islam, fikih adalah hasil penalaran dan refleksi manusia terhadap nash (teks kitab suci) sebagai upaya untuk menangkap makna tersembunyi maupun implikasi praktisnya. Para ahli fikih maupun kalam bersepakat bahwa Allah tidak boleh disebut sebagai faqih (jurist atau lawyer), karena tidak ada yang tersembunyi bagi-Nya. Oleh karena itu, fikih merupakan bagian dari kognisi manusia atau a matter of 
human cognition (idrak) dan pemahaman (fahm). Meminjam Ibnu Taimiyyah, hukum fikih merupakan pemahaman atau hasil bentukan kognisi dari para ahli agama atau fuqaha. Dengan demikian, sangat dimungkinkan memiliki kelemahan dan kekurangan. Dalam khazanah filsafat ilmu kontemporer, halhal yang terkait dengan isu-isu seperti ini dikenal dengan istilah the fallibility atau the corrigibility of knowledge (ilmu pengetahuan apapun, termasuk di dalamnya konsepsi dan teori keilmuan keagamaan yang disusun oleh para cerdik pandai [fuqaha/ulama] dapat saja mengalami kesalahan dan ketidaktepatan). Sebagai konsekuensinya, pemahaman fikih pada era tertentu dan tingkat capaian pendidikan manusia era tertentu serta perkembangan ilmu pengetahuan era tertentu dapat diperdebatkan dan dapat diubah ke arah yang tepat dan lebih baik. Dengan demikian, fikih merupakan persepsi dan interpretasi seseorang yang bersifat subjektif, baik secara individu maupun kelompok, golongan, mazhab, organisasi sosial keagamaan, dan sebagainya. Sayangnya, metode ijtihad fikih dan hasilnya seringkali dipersepsikan sebagai 'aturan Tuhan', yang tidak bisa diganggu gugat (Abdullah, 2013).

Berangkat dari pemahaman di atas, KHI merupakan produk hukum yang tercipta berdasarkan perpaduan fikih ulama' madzhab yang diakui dan sudah dikaji di berbagai kalangan akademisi berdasarkan konteks, corak budaya, dan politik pada masa itu. Tentunya, tidak menutup kemungkinan bahwa hukum yang dibuat pada masa itu tetap bisa/tidak selalu bisa diterapkan pada konteks sekarang, mengingat cepatnya perkembangan zaman. Berubahnya sebuah hukum bukanlah menjadi suatu hal yang mustahil berdasarkan atas sifat hukum itu sendiri yang bersifat dinamis tergantung pada konteks zamannya. Hal tersebut dapat terjadi bilamana hukum tersebut sudah dilihat kurang sesuai dengan budaya dan peradaban umat Islam di Indonesia.

KHI juga dapat dikatakan sebagai produk kognitif, dimana pembuatannya didasarkan pada fikih dan 'urf pada masa KHI itu dibuat. Selain itu, materi yang ada pada KHI khususnya tentang nusyuz juga sesuai dengan apa yang ada dalam nash. Akan tetapi, hal itu akan menjadi masalah jika _tatu yang diterapkan di Indonesia masih membawa atau menganut ekspresi-ekspresi _tatu pada zaman Arab dahulu dimana _tatu itu pertama kali dibuat. Oleh karena itu, penting kiranya mengkonsep kembali konsep nusyuz yang ada dalam kompilasi dengan sudut pandang kemashlahatan sesuai dengan corak kebiasaan dan pandangan bangsa Indonesia. Sehingga kanun yang dibuat dalam hal ini adalah KHI dapat menjadi sebuah_tatu yang sesuai dengan_tatute-statuta masyarakat dan budaya bangsa Indonesia. 


\section{b. Fitur Keterbukaan (Openness)}

Mengacu pada skema openness dan mekanisme openness yang pertama yaitu merubah suatu hukum dengan melihat pandangan dunia seorang fakih merupakan salah satu solusi dalam menghadapi tantangan dunia dan stagnasi hukum Islam atau fikih. Dengan alasan, umat Islam sekarang hidup di tengah era globalisasi yang sedang tumbuh dan hampir menyeluruh. Sistem negara bangsa (Nation State), ekonomi dunia yang saling berkaitan, penciutan dunia melalui komunikasi global dan sistem transportasi menjadi manifestasi nyata dari mesin globalisasi. Globalisasi memberikan cara pandang baru dan tantangan-tantangan kontemporer yang harus dihadapi oleh sejarah umat Islam. Mengatasi dampak dari globalisasi (modernitas) menjadi masalah utama yang harus dihadapi oleh umat Islam (Eposito, 2003).

Persoalan utama yang kini dihadapi dunia Islam adalah partisipasi politik dan demokratisasi, sistem ekonomi dan pendidikan yang gagal, berkembangnya ancaman ekstrimis religius (fundamentalis), dampak globalisasi, serta memupuk pluralisme dan pemahaman modern atas toleransi yang didasarkan pada sikap saling memahami. Bahkan menurut hasil survei United Nation Development Programme (UNDP) disebutkan bahwa indeks pertumbuhan manusia di dunia yang berpenduduk mayoritas muslim memperlihatkan tingkat yang sangat rendah. Rendahnya indeks pertumbuhan ini disebabkan oleh beberapa faktor penting, diantaranya masalah buta huruf, pendidikan, partisipasi ekonomi dan politik, pemberdayaan perempuan dan partisipasi mereka di panggung politik atau ruang publik (Auda, 2015).

Jasser menyebut pandangan dunia (worldview) dengan istilah welstanchauung sebuah istilah yang sudah berusia seratus tahun yang secara literal bermakna gambaran dunia. Pandangan dunia adalah seperngkat perkiraan yang kita pegangi tentang penyusunan dasar dunia. Jadi pandangan dunia merupakan produk dari sejumlah faktor yang membentuk kognisi manusia terhadap dunia (Auda, 2015). Pandangan dunia ini dibentuk oleh segala sesuatu disekitar kita, mulai dari agama, konsep hari, politik, budaya, geografi lingkungan masyarakat dan bahasa.

Dalam teori maqāșid-nya, Jasser merespon tantangan dan tuntutan era global dengan mereformasi maqasid menuju maqasid yang bercita rasa Pemuliaan Hak Asasi Manusia (HAM) dan Pengembangan Sumber Daya Manusia menjadi salah satu tema utama kemaslahatan publik masa kini. Implikasi reformasi ini adalah dengan mengadopsi konsep di atas sesuai dengan ukuran dari target-target kesepakatan atau ijma' Perserikatan 
Bangsa-Bangsa yang dalam hal ini merupakan penghapusan diskriminasi. Terkait gagasan tersebut, seyogyanya sebuah hukum yang dipandang sudah tidak sesuai dengan perkembangan zaman serta bertentangan dengan norma-norma di masyarakat dapat dirubah asalkan tidak menyimpang dari nilai-nilai filosofis dan dasar hukum itu sendiri. Nusyuz dalam KHI adalah salah satu dari sekian aturan atau hukum yang dirasa masih mengandung diskriminasi serta bertentangan dengan prinsip dasar Islam. Oleh karena itu, dengan mengacu pada pendekatan sistem dengan menggunakan fitur openness akan melihat konsep nusyuz dalam KHI dengan sudut pandang dunia khususnya HAM serta dengan menyandingkan tataran filosofis konsep nusyuz dalam KHI dalam beberapa regulasi di Indonesia.

Banyak instrumen hukum Internasional tentang hak asasi manusia yang menerapkan lebih jauh hak individu dan melindungi serta melarang diskriminasi terhadap kelompok-kelompok tertentu, khususnya perempuan. Secara umum konvensi dan kesepakatan ini mewajibkan negara-negara pihak untuk mengejar kebijakan penghapusan diskriminasi terhadap perempuan melalui upaya yang tepat dan segera. Ditegaskan kembali tentang persamaan hak asasi bagi perempuan dan laki-laki di dalam masyarakat dan keluarga. Negara-negara pihak diwajibkan untuk melakukan tindakan terhadap penyebab sosial dari ketidaksetaraan pada perempuan dan menyerukan untuk menghapuskan peraturan, stereotip, praktik dan prasangka yang merugikan kesejahteraan perempuan.

Fitur openness merupakan sebuah sistem untuk melihat suatu permasalahan dengan terbuka pada pandangan dunia. Hal ini juga selaras dengan sistem dalam pemikiran hukum Islam. Seluruh madzhab dan mayoritas ahli fikih selama berabad-abad telah setuju bahwa ijtihad itu sangat penting bagi hukum Islam, karena nash itu sifatnya terbatas, sedangkan peristiwa-peristiwa tidaklah terbatas. Berdasarkan uraian dan ketentuan di atas, dalam rangka memberi ruang fleksibilitas atau ruang gerak yang lebih elastis dalam hukum Islam atau fikih agar dapat menghadapi lingkungan dan permasalahan pada masa kini yang berubah dengan cepat. Komponen di atas sangatlah penting dalam menjawab permasalahan tentang ketidakadilan gender, yang dalam hal ini termaktub dalam Inpres No. 1 Tahun 1991 Kompilasi Hukum Islam khususnya tentang nusyuz. Ketidakadilan gender ini tertulis dengan jelas bahwasanya konsep nusyuz dalam KHI hanya untuk nusyuz istri, sedangkan nusyuz suami tidak disebutkan dalam aturan itu. Melihat fakta tersebut tentunya sangat bersinggungan dengan instrumen Hukum Internasional Hak Asasi Manusia yang sangat mendukung tentang kesetaraan antara laki-laki dan perempuan 
serta penghapusan diskriminasi diantara keduanya di dalam hukum. Disamping itu, negara juga berkewajiban merealisasikan ketentuanketentuan di atas untuk melindungi dan menjamin hak-hak perempuan di dalam masyarakat, khususnya dalam lingkup keluarga.

Tidak hanya bersinggungan dengan instrumen hukum Internasional tentang hak asasi manusia dan hak perempuan, di Indonesia juga terdapat beberapa regulasi yang bersinggungan dengan aturan di atas. Di antaranya Pancasila yang telah diterima sebagai dasar falsafah, ideologi negara dan pandangan hidup bangsa Indonesia, serta pembukaan UUD 1945 terdiri 4 (empat) alinea yang masing-masing alinea memiliki hubungan sangat jelas isi, susunan dan tujuannya (Soepardi, 2010).

Dalam pasal 27 ayat 1 UUD tahun 1945 disebutkan bahwa setiap warga negara mempunyai perlakuan yang sama di dalam hukum dan pemerintahan, dan pada pasal 28D ayat 1 secara tidak langsung menentang adanya diskriminasi dalam ranah hukum nasional. Berdasarkan analisis tersebut, maka konsep nusyuz dalam KHI yang dinilai mengandung unsur diskriminatif yakni: hanya mengatur nusyuz istri, harus dirubah dengan menambahkan nusyuz suami didalamnya. Hal ini didasarkan pada beberapa argumen; 1) Indonesia merupakan salah satu negara yang ikut dalam keanggotaan di Perserikatan Bangsa-Bangsa (PBB) yang secara otomatis terikat dalam hukum Internasional. Hukum Internasional yang dihasilkan dari Perkumpulan atau konvensi-konvensi tersebut mengikat pada Hukum Nasional dengan cara melalui ratifikasi. Untuk itu, terkait dengan penghapusan segala macam diskriminasi dan penghormatan terhadap hakhak perempuan harus dilakukan dengan mengubah aturan-aturan, undangundang dan pasal-pasal yang masih bersifat diskriminatif. Kedua, dalam konteks pengaturan HAM kaum perempuan di Indonesia yang dapat ditemui dalam UUD 1945 dan dalam beberapa regulasi yang sudah dijelaskan di atas, maka merubah konsep nusyuz dalam pasal KHI melalui pendekatan HAM tidaklah bertentangan dengan filosofi Negara serta aturan dan UndangUndang yang ada.

\section{c. Fitur kemenyeluruhan (Wholeness)}

Kemenyeluruhan adalah membenahi kelemahan usul fikih klasik yang sering menggunakan pendekatan reduksionis dan atomistic, yang terlihat dari sikap mengandalkan satu nash untuk menyelesaikan kasus-kasus yang dihadapi tanpa memandang nash-nash lain yang terkait. Solusi yang ditawarkan adalah menerapkan prinsip holisme melalui operasionalisasi tafsir tematik yang tidak lagi terbatas pada ayat-ayat hukum melainkan 
menjadikan seluruh ayat al-Qur'an sebagai pertimbangan dalam memutuskan hukum Islam (Auda, 2015).

Dalam kajian tafsir tematik, kata nusyuz dalam berbagai derivasinya ditemukan setidaknya lima kali dalam al-Qur'an seperti terdapat pada surat al-Mujadalah ayat 11, surat al-Baqarah ayat 259, dan dalam surat an-Nisa' ayat 34 serta 128. Dari kelima kata nusyuz yang terulang dari empat ayat di atas berasal dari kata nasyaza-yansyuzu-nusyuzan yang berarti tinggi atau timbul ke permukaan (Rohman, 2006). Nusyuz juga berarti perempuan yang durhaka terhadap suami (Al-Marbawi, 1995). Sedangkan dalam kamus istilah fikih nusyuz diartikan dengan durhaka, yaitu jika istri atau suami telah meninggalkan kewajiban-kewajibannya (Husein, dkk, 2003).

Secara terminologis, nusyuz adalah meninggalkan kewajiban bersuami-istri atau sikap acuh tak acuh yang di tampilkan oleh suami atau istri. Dapat ditegaskan bahwa nusyuz dalam rumah tangga adalah menunjukkan kebencian seorang suami kepada istrinya atau sebaliknya. Namun, lazimnya nusyuz itu diartikan sebagai durhaka atau kedurhakaan (Rohman, 2006).

Melihat sekilas dengan mengkaji dua ayat terakhir di atas dalam surat an-Nisa' ayat 34 dan 128 diperoleh pemahaman bahwa laki-laki sebagai suami ataupun perempuan sebagai istri sama-sama berpotensi untuk melakukan nusyuz. Jika dicermati kedua penafsiran terhadap surat an-Nisa' ayat 34 dan ayat 128 dalam beberapa pandangan para ulama terlihat adanya perbedaan indikasi nusyuz dari seorang suami dan istri. Seorang istri dianggap nusyuz jika ia tidak setia kepada suami yang akibatkan etika yang jelek. Sementara suami dianggap nusyuz jika ia tidak setia kepada istri serta sikap keengganan untuk menafkahi. Zuhaily mengatakan nusyuz seorang istri lebih dipengaruhi oleh sifat kelembutan akalnya, sementara nusyuz seorang suami lebih berkaitan dengan ketegasan sikapnya (Zuhayli, 2003).

Al-Maraghi menyebutkan bahwa perempuan yang shalihah adalah perempuan yang taat kepada suami dan menjaga hubungan-hubungan yang biasa (badaniyah) dan urusan-urusan khusus yang berkenaan dengan suami istri. Istri tidak diperbolehkan dilihat oleh lelaki lain meskipun kerabatnya, dan hendaknya memelihara kehormatan dari sentuhan tangan, pandangan mata, atau pendengaran telinga yang khianat. Dikategorikannya penolakan istri terhadap ajakan suami untuk "tidur" ke dalam kategori nusyuz menjadi sangat logis ketika didasarkan pada pemahaman bahwa "hubungan" suami istri adalah hubungan yang bersifat simbiosis-mutualisme bukan simbiosisparasitis, sehingga keengganan untuk memperhatikan hubungan tersebut 
menjadi ukuran ketidaksiapan untuk mentaati dan melaksanakan hal-hal lain yang secara nyata hanya akan bermanfaat bagi salah satunya.

Perbedaan lain yang tampak dari ayat 34 dan 128 surat an-Nisa' adalah terkait dengan penyelesaian nusyuz. Dalam ayat 34 yang berbicara tentang nusyuznya seorang istri, al-Quran memberikan tuntunan dengan tiga langkah, pertama, hendaklah seorang suami memberikan nasehat, kedua, berpisah tempat tidur, serta yang ketiga, suami boleh memukul dengan tujuan sebagai pengajaran. Namun ketika Allah berbicara tentang nusyuznya seorang suami seperti terungkap pada ayat 128 surat an-Nisa, justru jalan keluarnya adalah berdamai bahkan Allah menegaskan perdamaian adalah langkah yang paling baik (Salam, 2015).

Perbedaan di atas dijadikan sebagai unsur dari pendefnisian nusyuz sebagaimana yang terdapat dalam kamus istilah fikih. Dalam kamus tersebut, nusyuz didefnisikan sebagai kedurhakaan seorang suami atau istri manakala tidak memenuhi kewajibanya masing-masing. Istri dikatakan nusyuz manakala ia keluar rumah tanpa ijin suami dan dengan tujuan untuk membangkang, sedangkan suami dianggap nusyuz manakala ia bertindak keras kepada istri, tidak menggaulinya dan tidak pula memberikan nafah serta bersikap acuh tak acuh kepada istri. Jika nusyuz dilakukan oleh seorang istri maka hendaklah dinasehati dengan baik. Kemudian memisahkan tempat tidurnya manakala langkah pertama tidak berhasil, dan langkah yang terkahir adalah boleh dipukul dengan catatan tidak membahayakan, akan tetapi jika nusyuz dilakukan oleh seorang suami, maka langkah yang harus ditempuh adalah dengan berdamai (Mujieb, dkk, 1994).

Berbeda dengan pemahaman di atas, pemaknaan nusyuz menurut al Qur'an berdasarkan pada pembahasan empat ayat di atas, diperoleh satu pemaknaan bahwa nusyuz merupakan tindakan pengabaian terhadap hak dan kewajiban dalam rumah tangga yang menyebabkan kerenggangan hubungan keduanya. Pemaknaan ini didasarkan pada: pertama, dalam surat al-Mujadalah:11, term nusyuz dikaitkan dengan etika menghadiri majelis nabi, yaitu dengan cara tidak berdesak-desakan dan berdiri sebagai penghormatan terhadap Nabi. Tindakan ini dilakukan secara sadar dengan adanya motivasi tertentu minimal untuk menunjukkan penghormatan yang begitu tinggi kepada baginda nabi. Maka jika dikaitkan dengan tindakan nusyuz dalam kehidupan rumah tangga dapat dikatakan tindakan pengabaian hak dan kewajiban masing-masing suami istri tentunya harus dilakukan dalam keadaaan sadar dengan adanya niatan tertentu yang bisa saja karena keinginan untuk mengakhiri ikatan suami istri (Salam, 2015). 
Kedua, surat al-Baqarah ayat 259 mengisahkan kemahakuasaan Allah yang diperlihatkan kepada Raja Namrudz beserta para pengikutnya ketika mendebat Nabi Ibrahim tentang kekuasaan Allah yang dapat menghidupkan dan mematikan makhluk. Untuk membuktikan itu Allah memperlihatkan kekuasan-Nya dengan membuat tidur Nabi Uzair selama 100 tahun dan menghidupkan kembali dengan keadaan yang berbeda dengan zaman sebelumnya. Ketika Nabi Uzair dibangunkan kembali dia melihat sekelilingnya sudah rusak dan benar-benar berbeda dengan keadaannya dahulu. Seketika Allah mengembalikan makanan yang rusak dan keledai yang tinggal tulang belulang menjadi seperti sedia kala. Kisah tersebut menunjukkan bahwa Allah berkuasa atas segala-galanya dan pelecehan terhadap kecongkakan Namrudz. Bila hal ini dibawa kedalam konteks nusyuz dalam kehidupan rumah tangga, maka dapat dikatakan nusyuz suami ataupun istri ada karena tujuan merendahkan martabat salah satunya.

Ketiga, surat an-Nisa': 34 mempunyai kandungan dalam mencirikan perempuan atau perempuan shalihah sebagai perempuan yang qanitat dan hafidzat. Dalam kata lain nusyuz seorang istri dapat diindikasikan jika seorang istri: 1. Tidak bertakwa kepada Allah dan, 2. Tidak mampu menjaga kehormatan dirinya serta menjaga kehormatan suaminya. Keempat, surat an-Nisa': 128 menjelaskan tentang nusyuz seorang suami berkaitan dengan kelalaiannya atau keengganannya untuk memberikan nafkah lahir dan batin terhadap isterinya.

\section{d. Fitur Multi-Dimensionalitas (Multi-Dimensionality)}

Sebuah sistem bukanlah sesuatu yang tunggal, namun terdiri dari beberapa bagian yang saling terkait antara satu dengan lain. Di dalam sistem terdapat struktur yang koheren. Karena sebuah sistem terdiri dari bagianbagian yang cukup kompleks, maka ia memiliki spektrum dimensi yang tidak tunggal. Hukum Islam dapat dianalogikan seperti sistem. Hukum Islam adalah sebuah sistem yang memiliki berbagai dimensi. Terdapat dua konsep utama dalam memandang sistem secara multidimensi, yaitu pangkat (rank) dan tingkatan (level). Pangkat dalam kognisi multidimensi merepresentasikan banyaknya dimensi dalam bidang yang hendak dibahas. Adapun tingkatan merepresentasikan banyaknya level atau kadar proporsional yang mungkin ada pada suatu dimensi (Auda, 2015).

Prinsip ini digunakan Jasser a untuk mengkritisi akar pemikiran binary opposition di dalam hukum Islam. Menurutnya, dikotomi antara qath'i dan dzanni telah begitu dominan dalam metodologi penetapan hukum Islam, sehingga muncul istilah qat'iyyu al-dilalah, qat'iyyu al-subut, qat'iyyu al- 
mantiq. Paradigma oposisi binary harus dihilangkan untuk menghindari pereduksian metodologis, serta mendamaikan beberapa dalil yang mengandung pertentangan dengan mengedepankan aspek maqasid (tujuan utama hukum). Misalnya, perbedaan-perbedaan dalil dalam sunnah-sunnah tentang ibadah yang muncul hendaknya dilihat dari sisi perkembangan maqasid, perbedaan-perbedaan dalam hadits yang berkaitan dengan urf harus dilihat dari perspektif maqasid universalitas hukum Islam, serta keberadaan nash sebaiknya dilihat sebagai penetapan hukum yang bersifat gradual (Auda, 2015).

Konsep nusyuz dalam Kompilasi Hukum Islam hanya mengatur nusyuz yang dilakukan oleh pihak istri saja. Pengambilan hukum nusyuz dalam Kompilasi Hukum Islam masih berdasarkan fikih patriarkis yang mana didasarkan pada teks-teks agama yang pokok. Disamping itu, pola pikir madzhab tradisional hukum Islam seringkali terjebak pada pola berpikir satu dimensi berpikir (one-dimensional). Metode one-dimensional hanya terfokus pada satu faktor yang terdapat dalam satu kasus. Oleh karena itu, sebagian besar fatwa-fatwa yang dikeluarkan hanya berdasarkan satu dalil saja. Sering diistilahkan dengan dalil al-mas'alah (the evidence of case), meskipun sebenarnya selalu terbuka variasi dalil yang bermacam-macam (adillah) yang dapat diterapkan pada kasus yang sama dan menghasilkan keputusan hukum yang berbeda (Abdullah, 2013).

Konsep nusyuz di atas mencangkup dua hal: pertama, laki-laki hampir selalu menjadi aktor dan panutan di dalam lembaga agama. Berbagai penafsiran keagamaan banyak disampaikan melalui sudut pandang laki-laki dan melalui ucapan, maupun kekuasaan laki-laki. Kedua, perempuan dialienasi dari ranah ruang publik, sehingga banyak dari hak-haknya yang terampas.

Menanggapi fakta tersebut, penting dilakukan upaya untuk memunculkan penafsiran ulang konsep nusyuz berdasarkan fitur multidimensi dengan melihat nusyuz dengan berbagai dimensi yang berkaitan yakni dengan memperluas ruang lingkup rank dan level pada nusyuz, konsep nusyuz yang awalnya masuk pada rank agama diperluas cangkupannya dengan menambahkan dimensi sosial dengan kata lain HAM, sedangkan pada ranah level diperluas ruang lingkupnya menjadi universal. Oleh karena itu, konsep nusyuz dalam KHI yang masih mencangkup nusyuz istri saja, dapat ditambahkan konsep nusyuz suami didalamnya, dengan memaparkan dalil-dalil yang berkaitan serta sesuai dengan peradaban dan urf umat Islam sekarang. Sebagaimana sebuah kaidah fikih: "Tidak diingkari perubahan hukum disebabkan perubahan zaman dan tempat” (Uman, dkk, 2000). 
Demi menjawab permasalahan di atas, dalam fitur multidimensionalitasnya Jasser Auda menawarkan solusi al Jam' (konsiliasi) yaitu sebuah metode yang didasarkan oleh kaidah ushul fikih yang menyatakan: "I'mal al-nash awla min ihmalih", yang artinya menerapkan nash adalah lebih utama daripada mengabaikannya. Maka dalam rangka mengembangkan sebuah hukum sangat penting melihat dalil-dalil yang berkaitan dengan masalah tersebut, yakni dengan menambahkan dasar hukum nusyuz suami QS. An-Nisa' ayat 128 serta ayat-ayat tentang kesetaraan laki-laki dan perempuan.

Berdasarkan penjelasan di atas maka konsep nusyuz dalam Kompilasi Hukum Islam yang hanya mengatur tentang nusyuz istri saja jika di interpretasi ulang untuk mencapai kemashlahatan menurut fitur multidimensional menghasilkan konsep nusyuz bukan hanya berlaku pada istri saja, melainkan kepada suami juga, sehingga perempuan mendapatkan hak-haknya tanpa adanya diskriminasi serta laki-laki dan perempuan dapat berjalan seiring dalam peradaban umat Islam yang adil dan setara.

\section{e. Fitur Tujuan (Purposefulness)}

Menurut Jasser, realisasi maqasid merupakan dasar penting dan fundamental bagi sistem hukum Islam. Menggali maqasid harus dikembalikan kepada teks utama (al-Qur'an dan hadits), bukan pendapat atau pikiran faqih. Oleh karena itu, perwujudan tujuan (maqasid) menjadi tolok ukur dari validitas setiap ijtihad, tanpa menghubungkannya dengan kecenderungan ataupun madzhab tertentu. Tujuan penetapan hukum Islam harus dikembalikan kepada kemaslahatan masyarakat yang terdapat di sekitarnya dengan berorientasi pada perlindungan keluarga, kepedulian lebih terhadap institusi keluarga serta menjaga dan melindungi martabat kemanusiaan, menjaga dan melindungi hak-hak asasi manusia (Auda, 2015).

Jasser menyarankan pengembangan Maqāșid al-sharīah yang dulunya bernuansa penjagaan dan pelestarian menjadi Maqāșid al-sharīah yang bernuansa pengembangan dan pemuliaan hak-hak asasi. Disamping itu Jasser Auda juga menyarankan untuk memasukkan hak-hak asasi manusia sebagai menyusun tipologi teori hukum Islam kontemporer.

Pengembangan dan pemuliaan hak-hak asasi inilah yang menjadi salah satu tema utama yang dipandang penting bagi kemashlahatan publik pada zaman sekarang. Kemashlahatan publik pemuliaan hak-hak asasi seharusnya menjadi salah satu tujuan pokok Maqāșid al-sharīah yang direalisasikan melalui hukum Islam. Dengan mengadopsi konsep tentang hak-hak asasi dalam kacamata internasional dan tentunya dengan tidak 
menghilangkan aturan yang tertera pada hukum Islam, realisasi maqasid dapat di ukur secara empiris dengan mengambil manfaat dari target-target aturan tersebut.

Di samping itu, idealnya sebuah produk hukum yang efektif pada dasarnya dilatarbelakangi oleh tiga pilar yaitu filosofis, yuridis dan sosiologi. Pilar filosofis artinya hukum mempunyai kekuatan berlaku apabila hukum tersebut sesuai dengan cita-cita hukum tertinggi. Pilar yuridis artinya hukum mempunyai kekuatan berlaku apabila persyaratan formal terbentuknya telah terpenuhi. Sedangkan pilar sosiologis artinya hukum memiliki kekuatan berlaku dan dilaksanakan oleh masyarakat baik berlakunya dipaksakan oleh Negara maupun karena memang diterima atau diakui oleh masyarakat (Raharjo, 1991).

Berkaitan dengan konsep nusyuz dalam KHI yang secara umum terdapat pada pasal 84 sebenarnya sudah memenuhi pilar yuridis dan sosiologis. Akan tetapi bila ditinjau dari pilar filosofis KHI belum mengakomodasi nilai kesetaraan dan keadilan yang seharusnya diterapkan dalam salah satu pertimbangan dalam pembuatan hukum dalam sebuah aturan perundang-undangan. Dalam faktanya, konsep nusyuz dalam KHI dapat dikatakan masih bias gender atau masih memuat unsur diskriminatif. Konsep nusyuz dalam kompilasi hukum Islam, yaitu nusyuz hanya berlaku kepada istri saja, ini perlu adanya interpretasi ulang yang lebih mempertimbangkan unsur maslahah, agar tidak ada ketimpangan didalam hukum, sehingga tercermin bukan hanya kepastian hukum semata akan tetapi juga mengandung keadilan didalamnya.

Kesetaraan hak antara laki-laki dan perempuan merupakan salah satu objek kajian dalam pembuatan aturan berbagai konvensi dan deklarasi internasional tentang hak asasi manusia. Hal ini disebutkan salah satunya dalam The Universal Declaration of Human Rights (UDHR) yang menyatakan bahwa setiap orang berhak atas pengakuan sebagai pribadi di depan hukum dimana saja ia berada serta berhak atas perlindungan hukum yang sama tanpa diskriminasi apapun. Dengan demikian, seharusnya dalam pembuatan sebuah aturan, ketentuan ataupun hukum dalam Negara manapun tidak dibenarkan adanya diskriminasi apapun didalalamnya. Hal inipun juga secara eksplisit juga disebutkan dalam sejumlah aturan dan Undang-undang di Indonesia, salah satunya dalam Tap. MPR No. XVII/MPR/1998 tentang HAM bahwa menugaskan kepada lembaga-lembaga tinggi negara dan seluruh aparatur pemerintah, untuk menghormati, menegakkan dan menyebarluaskan pemahaman mengenai hak asasi manusia kepada seluruh masyarakat serta menugaskan kepada presiden republik Indonesia dan 
dewan perwakilan rakyat Republik Indonesia untuk meratifikasi berbagai instrumen perserikatan bangsa-bangsa tentang hak asasi manusia, sepanjang tidak bertentangan dengan Pancasila dan UUD tahun 1945.

Negara Indonesia juga menyetujui ketentuan tersebut untuk diterapkan asalkan tidak bertentangan dengan ideologi Negara yakni Pancasila dan UUD 1945. Berkaitan dengan KHI sendiri, yang notabenenya diperuntukkan untuk umat Islam, masih terdapat beberapa ketentuan didalamnya yang dipandang masih mengandung unsur ketidakadilan gender, salah satunya yakni terkait nusyuz. Aturan tentang nusyuz yang berlaku untuk istri saja, dirasa mengandung ketidakadilan gender, dimana menrut hasil dari fitur Wholeness bahwasanya nusyuz tidak hanya berlaku pada istri semata, akan tetapi juga kepada suami. Hal ini dibuktikan dengan adanya ayat yang menjelaskan tentang nusyuz suami yakni dalam surat an-nisa' ayat 128. Disamping itu, perubahan konsep nusyuz di atas sesuai dengan hasil dari fitur Openness, yakni perubahan hukum berdasarkan pada pandangan dunia, yang dalam hal ini adalah hak asasi manusia dan tentunya hal tersebut tidak pertentangan dengan aturan nusyuz dalam hukum Islam. Statement tersebut dapat dibuktikan jika melihat pembahasan dalam fitur Multidimensionality, dengan menggunakan metode konsiliasi atau al-Jam'.

Berdasarkan hasil interpretasi konsep nusyuz menurut fitur-fitur di atas, maka konsep nusyuz dalam KHI yang hanya berlaku untuk istri yang termaktub pada pada pasal 84 dapat dirumuskan ulang untuk mendapatkan konsep baru. Oleh karena itu, rumusan nusyuz yang ada dalam pasal $84 \mathrm{KHI}$ dapat ditambahkan sebuah konsep baru, yakni konsep nusyuz suami. Dengan kata lain, pada pasal 84 akan berbunyi:

1) Suami dapat dianggap nusyuz jika ia tidak melaksanakan kewajibankewajiban sebagaimana dimaksud dalam pasal 80 ayat (2),(3) dan (4) kecuali dengan alasan yang sah, sedangkan Istri dapat dianggap nusyuz jika ia tidak mau melaksanakan kewajiban-kewajiban sebagaimana dimaksud dalam pasal 83 ayat (1) kecuali dengan alasan yang sah.

2) Selama suami atau istri dalam keadaan nusyuz, kewajiban salah satu pihak kepada pihak lain tidak berlaku kecuali hal-hal untuk kepentingan anaknya.

3) Kewajiban salah satu pihak kepada pihak lain berlaku kembali sesudah salah satunya tidak nusyuz.

4) Ketentuan tentang ada atau tidak adanya nusyuz dari suami atau istri harus didasarkan atas bukti yang sah.

Adapun merubah konsep nusyuz menjadi berlaku untuk istri dan suami dilakukan dalam rangka mencapai "Maqasid from Protection and Preservation to Development and Rights". Selain itu, penambahan konsep 
nusyuz suami dalam KHI memiliki beberapa keunggulan, diantaranya adalah: 1) dari segi filosofis, konsep ini mengandung prinsip dasar Islam seperti persamaan (al-musawwah) dan keadilan (al-adallah) serta sejalan dengan nilai kesetaraan yang termaktub dalam Pancasila dan UUD 1945; 2) dari segi yuridis, konsep ini sesuai dengan aturan dan perundang-undangan yang berlaku di Indonesia, khususnya terkait penghapusan diskriminasi dan perlindungan HAM serta aturan-aturan dalam hukum Internasional tentang HAM. Sesuai dengan asas legalitas yang diatur dalam pasal 58 ayat 1 UU. No. 7 tahun 1989; 3) dari segi sosiologis, konsep ini telah mengakomodasi keadilan gender dalam nusyuz. Konsep ini juga sudah sesuai dengan konteks kebudayaan masyarakat Indonesia saat ini, dimana peran suami dan istri adalah seimbang saling melengkapi atau hubungan partnership.

\section{KESIMPULAN}

Ketentuan nusyuz dalam KHI, tidak sepenuhnya menjiplak atau hasil filterasi dari fikih klasik. Kendati esensi KHI dengan fikih klasik sama-sama menyudutkan hak-hak perempuan dibandingkan laki-laki, akan tetapi terdapat nilai-nilai hukum yang mempertemukan keduanya. Dengan demikian, relevansi antara fikih dengan KHI tertera dalam konsep nusyuz dan implikasi hukum tersirat dari pemahaman teks tertulis. Untuk memahami teks perundang-undangan maupun fikih, harus memahami tentang konsep teks dan tujuan dari dibuatnya teks tersebut. Maka dapat dipahami, relevansi keduanya terletak pada substansi nas atau teks. Adapun dari hasil rekonseptualisasi dapat disimpulkan bahwa nusyuz yang sesuai dengan corak kebudayaan masyarakat Indonesia saat ini serta demi penghapusan diskriminasi terhadap perempuan yang menjadi dasar pertimbangan analisis berdasarkan Maqāșid Syariah Jasser Auda yang bertema Pemuliaan Hak Asasi Manusia melalui pendekatan sistemnya, maka sebagaimana disebutkan dalam pasal 84 KHI perlu ditambahkan dengan konsep "nusyuz suami” yang secara umum bermakna bahwa nusyuz berlaku untuk kedua pihak, yakni suami dan istri. Karena itu, layak ditambahkan konsep nusyuz suami ke dalam konsep nusyuz dalam KHI sebagai hukum yang aplikatif dalam realitas masyarakat, responsif terhadap dinamika perubahan dan perkembangan masyarakat Muslim di Indonesia. Dengan rancangan konsep yang demikian, diharapkan dapat mengurangi diskriminasi dan ketidakadilan gender bagi perempuan. 


\section{DAFTAR PUSTAKA}

A. P. Kau, Sofyan. (2013). Metode Penelitian Hukum Islam Penuntun Praktis untuk Penulisan Skripsi dan Tesis. Yogyakarta: Mitra Pustaka.

Abdullah, M. A. (2013). Hak Kebebasan Beragama dan Berkeyakinan: Pendekatan Filsafat Sistem dalam Usul Fikih Sosial. Jurnal Salam, 14(1).

Al-Fairuzabadi Al-Syirazi, Ibn Yusuf. Al Muhadzhab Fi Fikih Imam Al-Syafi'I. .Surabaya: al-Hidayah. tt..

Ali, Mohammad Daud. (2015). Hukum Islam : Pengantar Ilmu Hukum dan Tata Huum Islam di Indonesia. Cet. Ke-21. .Jakarta: Raja Grafindo Persada.

Al-Marbawi, Muhammad Idris. (1995). Kamus Al-Marbawi .Semarang: AlNasyr.

al-Musthafa al-Maraghi, Ahmad. Tafsir al-Maraghi. Juz IV. .Beirut Lebanon: Daar al-Kutb al-Ilmiyah. t. th..

Arikunto, Suharsimi. (2013). Prosedur Penelitian Suatu Pendekatan Praktik. cet. 13. Jakarta; Rineka Cipta.

Auda, Jasser. (2015). Maqasid Shariah As Philosophy Of Islamic Law: A Systems Approach. Rosidain dan Ali Abdul Mun'im .trj.. Membumikan Hukum Islam Melalui Maqāșid al-sharīah. Bandung: PT. Mizan Pustaka.

Esposito, John L.. (2003). Unholy War: Teror Atas Nama Agama. terj. Syafruddin Hasani. Yogyakarta: Ikon.

Ibrahim, Johny. (2004). Teori dan Penelitian Hukum Normatif. .Malang; Bayumedia Publishing. 2007. Khoiruddin Nasution. Hukum Perkawinan I : Dilengkapi Perbandingan UU Negara Muslim Kontemporer. cet. Ke-1. Yogyakarta: ACAdeMIA + TAZZAFA.

Izutsu, Toshihiko. (2003). Relasi Tuhan dan Manusia. Terjemahan oleh Agus Fahri Husein dkk.. Yogyakarta: PT. Tiara Wacana.

Khallaf, Abdul Wahab. (2004). 'Ilmu Ushul al-Fikih. cet. ke-2. Kairo: Maktabah ad-Da'wah. 
Marzuki, Peter Mahmud. (2016). Penelitian Hukum. Edisi Revisi. Jakarta; Prenadamedia Group.

Muhammad, Abdul Kadir. (2004). Hukum dan Penelitian Hukum. Bandung: Citra Aditya Bakti.

Mujieb, M. Abdul. dkk.. (1994). Kamus Istilah Fikih. Jakarta: Pustaka Firdaus.

Raharjo, Satjipto. (1991). Ilmu Hukum. Bandung: Citra Aditya Bhakti.

Rohman, Dudung Abdul. (2006). Mengembangkan Etika Berumah Tangga Menjaga Moralitas Bangsa Menurut Pandangan Al-Qur'an. Bandung: Nuansa Aulia.

Rumidi, Sukandar. (2006). Metodologi Penelitian; Petunjuk Praktis Untuk Peneliti Pemula. Yogyakarta: Gajah Mada Universitas Press.

Salam, N. (2015). Konsep Nusyuz dalam Perspektif Al-Qur'an (Sebuah Kajian Tafsir Maudhu'i). De Jure: Jurnal Hukum dan Syar'iah, 7(1), 47-56.

Soemito, Ranny Hanitijo. (1990). Metodologi Penelitian Hukum dan Jurimetri. Jakarta: Ghimia Indonesia.

Soepardi. H.R.B.. (2010). Pancasila dan Undang-Undang Dasar Negara Republik Indonesia Tahun 1945. Jakarta: PT. Pustaka Mandiri.

Uman, Chaerul dkk. (2000). Ushul Fiqh 1. Bandung: CV PUSTAKA SETIA.

Wahid, Marzuki. (2014). Fiqh Indonesia. Bandung: Penerbit Marja.

Zahrah, Muhammad Abu. (1994). Ushul al-Fikih. .terj.. Saefullah Ma'shum. Ushul Fikih. Jakarta: Pustaka Firdaus.

Zuhayli, Wahbah. (2003). at-Tafsir al-Munir $f$ al-Aqidah wa asy-Syariah wal Manhaj .Jilid 3.. Damaskus: Dar al-Fikr. 